\title{
Penerapan Error Correction Mechanism (ECM) Model: Pengaruh Perdagangan Internasional dan Penanaman Modal Asing (PMA) terhadap PDB Indonesia
}

\author{
Haryono ${ }^{1, \text { a) }}$ \\ ${ }^{1}$ Badan Pusat Statistik Provinsi Jawa Timur, Jalan Raya Kendangsari Industri No.43-44, Kendangsari, \\ Kec. Tenggilis Mejoyo, Kota Surabaya, Jawa Timur 60292 \\ Email: ${ }^{a}$ Har.yono@bps.go.id
}

\begin{abstract}
Indonesia adheres to an open economic system. In carrying out its economy, Indonesia interacts with other countries through international trade transactions and capital flows. This research analyzes the impact of foreign trade and Foreign Direct Investment (FDI) on Indonesia's Gross Domestic Product (GDP) from the first quarter of 2015 to the second quarter of 2021. The analytical method used was the Error Correction Mechanism (ECM). The results of the ECM analysis showed that in the short and long run, exports and imports significantly influence Indonesia's GDP while FDI did not significant. Exports had a positive impact on GDP, while imports had a negative impact. The implementation of an export increase strategy and the selection of an effective and efficient import policy is very important in increasing GDP. In addition, the capacity of human resources needs to be encouraged to increase the absorption of capital and technology transfers from abroad.
\end{abstract}

Keywords: export, import, foreign investment

\begin{abstract}
Abstrak
Indonesia menganut sistem perekonomian terbuka. Dalam menjalankan ekonominya, Indonesia menjalin interaksi dengan negara lain melalui transaksi perdagangan internasional dan aliran modal. Penelitian ini menganalisis pengaruh perdagangan luar negeri dan Penanaman Modal Asing (PMA) terhadap Produk Domestik Bruto (PDB) Indonesia selama periode triwulan I 2015 hingga triwulan II 2021. Metode analisis yang digunakan adalah Error Corection Mechanism (ECM). Hasil analisis ECM menunjukkan bahwa dalam jangka waktu pendek dan panjang, variabel ekspor dan impor berpengaruh signifikan terhadap PDB sedangkan PMA tidak berpengaruh signifikan. Ekspor memberikan dampak positif terhadap PDB, sebaliknya impor berdampak negatif. Implementasi strategi peningkatan ekspor dan pemilihan kebijakan impor yang efektif dan efisien sangat penting dalam meningkatkan PDB. Selain itu, kapasitas sumber daya manusia perlu didorong untuk meningkatkan penyerapan transfer modal dan teknologi dari luar negeri.
\end{abstract}

Kata-kata kunci: ekspor, impor, investasi asing 


\section{PENDAHULUAN}

Salah satu indikator penting yang mencerminkan keberhasilan pembangunan ekonomi suatu negara adalah pertumbuhan ekonomi. Pertumbuhan ekonomi dapat diartikan sebagai peningkatan kemampuan ekonomi suatu negara dalam memproduksi barang dan jasa dalam jangka waktu tertentu. Pertumbuhan ekonomi suatu negara pada suatu periode dapat dihitung dari besarnya peningkatan nilai Produk Domestik Bruto (PDB) riil negara tersebut dibanding periode sebelumnya.

Berdasarkan World Bank (2021), Indonesia merupakan salah satu negara berpendapatan menengah ke bawah (lower-middle income country). Dalam menjalankan perekonomian, Indonesia menerapkan model ekonomi terbuka dengan menjalin interaksi ekonomi dengan negara lain di dunia. Interaksi ekonomi suatu negara dengan dunia internasional dilakukan melalui kegiatan ekspor impor barang dan jasa, serta aliran permodalan atau net capital outflow (Mankiw, 2018). Pada model ekonomi tersebut, akan terjadi interaksi perdagangan antar negara yang didasarkan pada keunggulan komparatif masingmasing negara. Selain itu, akan terjadi aliran modal serta ilmu pengetahuan dan teknologi antar negara yang diharapkan dapat mendorong pertumbuhan ekonomi. Dalam teori pertumbuhan ekonomi SollowSwan, teknologi merupakan salah satu faktor pendorong pertumbuhan ekonomi selain modal dan tenaga kerja (Amalia, Kiftiah, \& Sulistianingsih, 2016).

Penelitian tentang dampak interaksi ekonomi suatu negara dengan negara lain telah dilakukan oleh para peneliti di dunia. Lawal \& Ezeuchenne (2017) yang melakukan penelitian tentang perdagangan internasional dan pertumbuhan ekonomi di Nigeria menggunakan Vector Error Correction Model (VECM) menyatakan bahwa ekspor, impor, balance of trade, dan trade openness memberikan pengaruh signifikan bagi pertumbuhan ekonomi Nigeria dalam jangka panjang. Namun pada jangka pendek, hanya variabel ekspor dan balance of trade yang secara signifikan memengaruhi pertumbuhan ekonomi Nigeria. Alotaibi, Almohaimeed, \& Alharbi (2020) dalam penelitiannya tentang dampak perdagangan internasional terhadap pertumbuhan ekonomi Arab Saudi dengan Engle-Granger and Johansen's Tests for Cointegration dan Error Correction Model (ECM) menemukan bahwa variabel ekspor memberikan pengaruh bagi pertumbuhan ekonomi, dimana pengaruh yang diberikan berlaku pada jangka waktu panjang maupun pendek. Sementara itu, variabel impor dan pertumbuhan ekonomi tidak saling berhubungan satu sama lain pada jangka pendek. Raghuramapatruni \& Chaitanya (2020) dalam penelitiannya tentang dampak perdagangan internasional terhadap pertumbuhan ekonomi India dengan pendekatan Autoregressive Distributive Lag Model (ARDL) mengemukakan bahwa, dalam jangka panjang ekspor dan investasi domestik memberikan dampak positif dan signifikan terhadap PDB India. Sementara itu, impor dan kurs berdampak negatif namun tidak signifikan terhadap PDB India.

Dalam lingkup perekonomian di kawasan ASEAN, penelitian oleh Purnama \& Yao (2019) menggunakan Pedroni Panel Co-Integration dan Panel Vector Error Correction Model menemukan bahwa terdapat hubungan antara perdagangan internasional dan pertumbuhan ekonomi negara-negara di ASEAN. Dalam jangka panjang, perdagangan internasional dan penanaman modal langsung berdampak positif terhadap pertumbuhan ekonomi, sedangkan kurs berdampak negatif. Penelitian Purnomo (2020) dengan analisis regresi data panel dengan Fixed Effect Model (FEM) menyatakan bahwa Penanaman Modal Asing (PMA) berpengaruh signifikan dan positif terhadap pertumbuhan ekonomi negara-negara ASEAN selama periode 2000-2017. Secara lebih spesifik, Nguyen (2020) yang melakukan penelitian tentang dampak PMA dan perdagangan internasional di Vietnam dengan Ordinary Least Square (OLS) model menemukan bahwa ekspor dan PMA berdampak signifikan dan positif bagi pertumbuhan ekonomi Vietnam. Di sisi lain, impor memberikan dampak negatif namun tidak signifikan bagi pertumbuhan ekonomi di negara tersebut. Untuk perekonomian Indonesia, Astuti \& Ayuningtyas (2018) melakukan penelitian mengenai pengaruh variabel ekspor dan impor bagi pertumbuhan ekonomi Indonesia dengan data sekunder selama tahun 2000-2016 menggunakan metode Error Correction Model (ECM) menemukan bahwa pada jangka waktu yang panjang, variabel ekspor dan kurs memberikan pengaruh signifkan bagi pertumbuhan ekonomi, namun impor tidak memberikan pengaruh yang signifikan. Sementara dalam jangka waktu yang relatif pendek, nilai ekspor dan impor berdampak signifikan bagi kondisi pertumbuhan ekonomi, sementara kurs tidak memberikan pengaruh signifikan. Susanti \& Sholeh (2020) dalam penelitiannya mengenai dampak variabel makroekonomi 
dan perdagangan internasional terhadap pertumbuhan ekonomi Indonesia menggunakan data sekunder selama periode kuartal pertama 2009 hingga kuartal pertama 2020 dengan Ordinary Least Square (OLS) model menyatakan bahwa impor, suku bunga dan kurs memengaruhi pertumbuhan ekonomi Indonesia, sedangkan ekspor dan inflasi tidak berpengaruh.

Stasioneritas data merupakan hal yang penting dalam pemodelan menggunakan data deret waktu. Data dikatakan stasioner jika memiliki nilai rata-rata, varians, serta kovarian (pada berbagai lag) yang konstan sepanjang waktu. Apabila data yang tidak stasioner digunakan dalam pemodelan regresi, maka akan menghasilkan regresi palsu (spurious regression), dimana model yang dihasilkan memiliki koefisien determinasi yang tinggi, namun tidak memiliki hubungan yang berarti antar variabel (Gujarati \& Porter, 2009). Bahkan menurut Yule dalam Gujarati \& Porter (2009), meskipun digunakan jumlah sampel yang besar dalam suatu pemodelan, akan tetap terbentuk korelasi palsu dalam deret waktu yang tidak stasioner. Menurut Astuti \& Saputro (2018), apabila dibentuk persamaan regresi dari beberapa variabel yang tidak stasioner, umumnya akan dihasilkan residual yang tidak stasioner. Akan tetapi, tak jarang residual yang terbentuk bersifat stasioner, yang dapat diartikan bahwa terdapat kointegrasi antara variabel-variabel tersebut. Astuti \& Saputro (2018) menambahkan jika terdapat kointegrasi antar variabel, maka permasalahan regresi lancung terselesaikan serta membuktikan adanya hubungan keseimbangan (equilibrium) antar variabel, meskipun dalam jangka pendek terdapat kemungkinan terjadi ketidakseimbangan (disequilibrium) antara variabel satu sama lain. Berdasarkan Granger Representation Theorem, jika terdapat beberapa variabel yang terkointegrasi, maka hubungan antar variabel dapat dijelaskan melalui Error Correction Mechanism (Gujarati \& Porter, 2009).

Penelitian ini bertujuan untuk mengetahui dampak perdagangan internasional dan PMA terhadap PDB Indonesia selama periode tahun 2015 hingga semester pertama tahun 2021. Dalam penelitian ini, perdagangan internasional direpresentasikan dengan variabel ekspor luar negeri dan impor luar negeri. Variabel ekspor dan impor yang digunakan tidak hanya mencakup nilai transaksi perdagangan barang, namun juga mencakup nilai transaksi perdagangan jasa antar negara.

\section{METODOLOGI}

\section{Bahan dan Data}

Penelitian ini menggunakan data runtun waktu (time series). Periode yang digunakan berupa periode triwulanan, yakni triwulan I 2015 sampai dengan triwulan II 2021, sehingga jumlah observasi dalam penelitian ini sebanyak 26 observasi. Data yang digunakan adalah data sekunder yang diperoleh dari Kementerian Investasi/Badan Koordinasi Penanaman Modal (BKPM) dan Badan Pusat Statistik (BPS). Data PDB, ekspor, dan impor diperoleh dari BPS sedangkan data PMA diperoleh dari BKPM.

Variabel dalam penelitian ini dibagi ke dalam dua kelompok, yaitu variabel terikat dan bebas. PDB Indonesia digunakan sebagai variabel terikat, sedangkan ekspor, impor, dan PMA digunakan sebagai variabel bebas. PDB merupakan total nilai tambah yang diciptakan oleh semua unit usaha di suatu negara. Pada penelitian ini, PDB yang digunakan adalah PDB atas dasar harga konstan 2010 yang menunjukkan nilai tambah barang dan jasa yang dihitung berdasarkan harga yang berlaku pada tahun 2010. Penggunaan PDB atas dasar harga konstan sebagai variabel terikat dilandasi alasan bahwa pertumbuhan ekonomi suatu negara ditentukan oleh kenaikan PDB atas dasar harga konstan dari waktu ke waktu. Nilai PDB yang digunakan dalam satuan miliar rupiah.

Kegiatan ekspor dan impor merupakan transaksi alih kepemilikan (ekonomi) atas barang dan jasa antara residen suatu perekonomian dengan non residen. Prinsip pencatatan transaksi ekspor dan impor menggunakan prinsip akrual. Untuk transaksi barang, pengalihan kepemilikan didasarkan pada waktu pencatatan pada dokumen kepabeanan. Untuk transaksi jasa, pengalihan kepemilikan didasarkan pada saat jasa tersebut disediakan atau diberikan kepada penggunanya (BPS, 2021). Ekspor adalah nilai barang dan jasa yang dialihkan kepemilikannya dari pihak residen Indonesia ke pihak non residen. Nilai ekspor yang digunakan dalam satuan miliar rupiah. Impor diartikan sebagai nilai barang dan jasa yang dialihkan kepemilikannya dari pihak non residen Indonesia ke pihak residen Indonesia. Nilai impor yang digunakan dalam satuan miliar rupiah. 
PMA adalah kegiatan menanam modal untuk melakukan usaha di wilayah negara Republik Indonesia yang dilakukan oleh penanam modal asing, baik yang menggunakan modal asing sepenuhnya maupun yang berpatungan dengan penanam modal dalam negeri (Republik Indonesia, 2007). Nilai PMA yang digunakan dalam satuan ribu USD.

\section{Metode Penelitian}

Penelitian ini menggunakan metode analisis deskriptif dan Error Corection Mechanism (ECM). Dalam analisis ECM, disyaratkan seluruh variabel penelitian tidak stasioner pada tingkat level, namun stasioner pada derajat integrasi (orde) yang sama sehingga terbentuk kointegrasi antar variabel (Safitri \& Yuliana, 2020). Dengan alat analisis ini dapat diperoleh informasi hubungan antara variabel terikat dan variabel bebas baik dalam jangka panjang maupun jangka pendek.

Model umum persamaan jangka panjang adalah

$$
y_{t}=\alpha_{0}+\alpha_{1} x_{t}+\varepsilon_{t}
$$

Dimana,

$y_{t} \quad$ variabel terikat periode ke- $t$

$x_{t} \quad$ : variabel bebas periode ke- $t$

$\alpha_{0} \quad$ : konstanta persamaan jangka panjang

$\alpha_{1} \quad$ : koefisien persamaan jangka panjang

$\varepsilon_{t} \quad$ : residual persamaan jangka panjang

Model umum persamaan jangka pendek adalah

$$
\Delta y_{t}=\beta_{0}+\beta_{1} \Delta x_{t}+\beta \hat{\varepsilon}_{t-1}+v_{t}
$$

Dimana,

$\Delta y_{t}$ : first difference variabel terikat periode ke- $t\left(y_{t}-y_{t-1}\right)$

$\Delta x_{t}$ : first difference variabel bebas periode ke- $t\left(x_{t}-x_{t-1}\right)$

$\beta_{0}$ : konstanta persamaan jangka pendek

$\beta_{1}$ : koefisien persamaan jangka pendek

$\beta \quad$ : koefisien koreksi ketidakseimbangan (speed of sdjustment)

$\hat{\varepsilon}_{t-1}$ : Error Corection Term atau ECT (lag pertama residual persamaan jangka panjang)

$v_{t}$ : residual persamaan jangka pendek

Tahap pertama analisis data dalam penelitian ini adalah Uji Stasioneritas atau Uji Akar Unit (unit root test). Pengujian data dilakukan pada seluruh variabel, baik variabel terikat maupun bebas. Dalam penelitian ini, uji stasioneritas yang digunakan adalah Augmented Dickey-Fuller (ADF) test. Hipotesis nol $\left(\mathrm{H}_{0}\right)$ dari uji statistik ini adalah ada akar unit atau data tidak stasioner dan hipotesis alternatif $\left(\mathrm{H}_{1}\right)$ adalah tidak ada akar unit atau data stasioner. Hasil penghitungan dari besaran statistik uji pada ADF test kemudian dibandingkan dengan nilai kritis MacKinnon. Jika nilai absolut dari statistik uji lebih kecil dibandingkan nilai absolut dari titik kritis MacKinnon atau nilai $p$-value lebih besar dari tingkat signifikansi, maka hipotesisi nol diterima dan disimpulkan ada akar unit (data tidak stasioner). Sebaliknya, apabila nilai absolut dari statistik uji lebih besar dibandingkan nilai absolut titik kritis MacKinnon atau $p$-value lebih kecil dari tingkat signifikansi, maka hipotesis nol ditolak dan disimpulkan tidak ada akar unit (data telah stasioner).

Tahap selanjutnya adalah pembentukan persamaan jangka panjang dan pengujian kointegrasi. Apabila seluruh variabel penelitian stasioner di orde yang sama dan tidak stasioner di tingkat level, maka diduga ada kointegrasi antar variabel dalam jangka panjang. Persamaan jangka panjang dibentuk 
dengan meregresikan data yang tidak stasioner di tingkat level. Dalam penelitian ini, dibentuk model persamaan jangka panjang sebagai berikut:

$$
\ln P D B_{t}=\alpha_{0}+\alpha_{1} \ln E K S_{t}+\alpha_{2} \ln I M P_{t}+\alpha_{3} \ln P M A_{t}+\varepsilon_{t}
$$

$$
\begin{array}{ll}
\begin{array}{l}
\text { Dimana, } \\
\ln P D B_{t}
\end{array} & : \text { logartima natural PDB periode ke- } t \\
\ln E K S_{t} & : \text { logartima natural ekspor periode ke- } t \\
\ln I M P_{t} & : \text { logartima natural impor periode ke- } t \\
\ln P M A_{t} & : \text { logartima natural PMA periode ke- } t \\
\alpha_{0} & : \text { konstanta persamaan jangka panjang } \\
\alpha_{1}, \alpha_{2}, \alpha_{3} & : \text { koefisien persamaan jangka panjang } \\
\varepsilon_{t} & : \text { residual persamaan jangka panjang }
\end{array}
$$

Pembuktian adanya kointegrasi antar variabel dilakukan melalui pengujian stasioneritas residual dari persamaan jangka panjang menggunakan ADF test. Jika residual dari persamaan tersebut telah bersifat stasioner di tingkat level, maka dapat disimpulkan ada kointegrasi antar variabel. Apabila terdapat kointegrasi antar variabel, maka dapat diartikan bahwa ad hubungan jangka panjang di antara variabel-variabel penelitian.

Tahap ketiga adalah pembentukan persamaan jangka pendek. Model persamaan jangka pendek dibentuk dengan meregresikan variabel terikat dan variabel bebas yang telah stasioner pada ordo yang sama serta menambahkan variabel Error Corection Term (ECT) (Iladini \& Agustina, 2020). Pada penelitian ini digunakan orde pertama (first difference) dalam membentuk persamaan jangka pendek. Variabel ECT diperoleh dari nilai lag pertama residual persamaan jangka panjang $\left(\hat{\varepsilon}_{t-1}\right)$. Penambahan variabel ini dapat menggambarkan besarnya koreksi ketidakseimbangan yang mungkin terjadi pada jangka pendek menuju keseimbangan jangka panjang. Model persamaan jangka pendek dalam penelitian ini adalah

$$
d \ln P D B_{t}=\beta_{0}+\beta_{1} d \ln E K S_{t}+\beta_{2} d \ln I M P_{t}+\beta_{3} d \ln P M A_{t}+\beta_{4} E C T_{t-1}+v_{t}
$$

Dimana,

$$
\begin{array}{ll}
d \ln P D B_{t} & : \text { first difference logartima natural PDB periode ke- } t\left(\ln P D B_{t}-\ln P D B_{t-1}\right) \\
d \ln E K S_{t} & : \text { first difference logartima natural ekspor periode ke- } t\left(\ln E K S_{t}-\ln E K S_{t-1}\right) \\
d \ln I M P_{t} & : \text { first difference logartima natural impor periode ke- } t\left(\ln I M P_{t}-\ln I M P_{t-1}\right) \\
d \ln P M A_{t} & : \text { first difference logartima natural PMA periode ke- } t\left(\ln P M A_{t}-\ln P M A_{t-1}\right) \\
\beta_{0} & : \text { konstanta persamaan jangka pendek } \\
\beta_{1}, \beta_{2}, \beta_{3} & : \text { koefisien persamaan jangka pendek } \\
\beta_{4} & : \text { koefisien koreksi ketidakseimbangan (speed of sdjustment }) \\
E C T_{t-1} & : \text { Error Corection Term }\left(\hat{\varepsilon}_{t-1}=\right.\text { lag pertama residual persamaan jangka panjang) } \\
v_{t} & : \text { residual persamaan jangka pendek }
\end{array}
$$

Penambahan variabel ECT akan menghasilkan nilai speed of adjustment yang ditunjukkan oleh nilai koefisien regresi dari variabel tersebut $\left(\beta_{4}\right)$. Dalam penerapan model ECM, untuk mencapai keseimbangan jangka panjang, maka nilai koefisien regresi ECT harus signifikan secara statistik (Enders, 2015). Selain itu, nilai koefisien ECT juga harus bernilai negatif dalam rentang -1 hingga 0, sehingga variabel-variabel semakin mendekati kondisi keseimbangan dalam jangka panjang (Iladini \& Agustina, 2020). Koefisien ECT yang bernilai negatif dapat mencerminkan tingkat penyesuaian terhadap kondisi disequilibrium, apabila koefisien regresi ECT tidak signifikan maka asumsi 
equilibrium tidak dapat terpenuhi yang berarti bahwa data empiris dan teori tidak sejalan (Sugiarto \& Merissa, 2016).

Tahap keempat adalah uji keberartian model dengan uji simultan (uji F) dan uji parsial (uji t). Pengujian keberartian model digunakan untuk mengetahui kemampuan model yang terbentuk dalam menjelaskan hubungan antara variabel terikat dan bebas. Uji $\mathrm{F}$ bertujuan untuk mengetahui pegaruh seluruh variabel bebas, yakni ekspor, impor dan PMA secara serentak terhadap PDB. Uji t digunakan untuk mengetahui pengaruh masing-masing variabel bebas terhadap PDB secara individu.

Tahap terakhir yakni pengujian asumsi klasik Gauss-Markov yang terdiri dari normalitas, non autokorelasi, homoskedastititas dan non multikolinieritas. Pembentukan model ECM dilakukan dengan estimasi Ordinary Least Square (OLS), sehingga untuk menghasilkan estimator bersifat Best Linear Unbiassed Estimator (BLUE) diperlukan penerapan asumsi-asumsi tersebut.

Dalam penelitian ini, pengujian asumsi normalitas dilakukan dengan Jarque-Bera (JB) Test of Normality. Hipotesis nol $\left(\mathrm{H}_{0}\right)$ uji statistik ini adalah data mengikuti distribusi normal dan hipotesis alternatif $\left(\mathrm{H}_{1}\right)$ adalah data tidak berdistribusi normal. Statistik uji dalam Jarque-Bera (JB) Test adalah

$$
J B=n\left[\frac{S^{2}}{6}+\frac{(K-3)^{2}}{24}\right] \sim \chi_{2}^{2}
$$

Dimana,

$$
\begin{array}{ll}
n & : \text { jumlah sampel } \\
S & : \text { koefisien skewness } \\
K & : \text { koefisien kurtosis }
\end{array}
$$

Statistik uji JB Test mengikuti distribusi Chi-Square dengan degree of freedom (df) bernilai dua, apabila nilai JB mendekati nol atau nilai $p$-value lebih besar dari tingkat signifikansi, maka hipotesis nol diterima dan disimpulkan bahwa data (residual) mengikuti distribusi normal dan asumsi normalitas terpenuhi. Sebaliknya, apabila nilai JB jauh dari nol atau $p$-value lebih kecil dari tingkat signifikansi, maka hipotesis nol ditolak dan asumsi normalitas terlanggar.

Pengujian asumsi non autokorelasi dilakukan dengan Breusch-Godfrey (BG) Test. Hipotesis nol $\left(\mathrm{H}_{0}\right)$ BG Test adalah data tidak mengandung autokorelasi dan hipotesis alternatif $\left(\mathrm{H}_{1}\right)$ adalah data mengandung autokorelasi. Statistik uji BG Test adalah

$$
(n-p) R^{2} \sim \chi_{p}^{2}
$$

Dimana,

$n \quad$ : jumlah sampel

$p \quad$ : panjang lag optimal

$R^{2}$ : koefisien determinasi dari regresi residual bersama seluruh variabel bebas dan residual periode-periode sebelumnya

Apabila nilai $p$-value lebih besar dari tingkat signifikansi, maka hipotesis nol diterima dan disimpulkan bahwa data tidak mengandung autokorelasi dan asumsi non autokorelasi terpenuhi. Sebaliknya, apabila nilai p-value lebih kecil dari tingkat signifikansi, maka hipotesis nol ditolak dan asumsi non autokorelasi terlanggar.

Pengujian asumsi homoskedastisitas dilakukan dengan Breusch-Pagan-Godfrey (BPG) Test. Hipotesis nol $\left(\mathrm{H}_{0}\right)$ BPG Test adalah data memiliki varians konstan (homoskedastisitas) dan hipotesis alternatif $\left(\mathrm{H}_{1}\right)$ adalah data memiliki varians tidak konstan (heteroskedastisitas). Statistik uji pada BPG Test adalah

$$
\Theta=\frac{1}{2} E S S \sim \chi_{m-1}^{2}
$$


Dimana,

$\Theta \quad$ : Statistik Uji Breusch-Pagan-Godfrey $(B P G)$

ESS : Explained Sum of Squares

$m$ : banyaknya konstanta dan koefisien regresi

Statistik uji BPG Test mengikuti distribusi Chi-Squre dengan degree of freedom (df) bernilai m-1, dimana $m$ adalah banyaknya konstanta dan koefisien regresi dalam model. Apabila nilai $p$-value lebih besar dari tingkat signifikansi, maka hipotesis nol diterima dan disimpulkan bahwa data memiliki varians yang konstan dan asumsi homoskedastisitas terpenuhi. Sebaliknya, apabila nilai $p$-value lebih kecil dari tingkat signifikansi, maka hipotesis nol ditolak dan asumsi homoskedastisitas terlanggar.

Asumsi non multikolinearitas antar variabel dideteksi dari nilai Variance Inflation Factors (VIF). VIF menggambarkan seberapa besar dependensi antar variabel bebas dalam model regresi. Jika nilai VIF variabel lebih dari 10, maka diindikasikan terdapat kolinieritas yang tinggi antar variabel bebas (Gujarati \& Porter, 2009). VIF dengan persamaan sebagai berikut

$$
V I F=\frac{1}{\left(1-R_{j}^{2}\right)}
$$

\section{Dimana,}

VIF : Variance Inflation Factors

$R_{j}^{2}$ : Koefisien diterminasi variabel bebas ke-j dengan variabel lain

\section{HASIL DAN PEMBAHASAN}

Perkembangan perdagangan luar negeri dan PMA Indonesia dari triwulan pertama 2015 hingga triwulan kedua 2021 tersaji pada GAMBAR 1. Dalam periode tersebut tren nilai ekspor, impor dan PMA Indonesia mengalami kenaikan. Namun pada triwulan ketiga 2018 hingga triwulan kedua 2020, nilai transaksi perdagangan luar negeri Indonesia cenderung melemah sedangkan nilai PMA relatif stagnan. Kondisi ini disebabkan oleh perlambatan pertumbuhan ekonomi negara-negara mitra dagang utama Indonesia, sentimen perang dagang serta perlambatan arus perdagangan internasional akibat pandemi COVID-19. Tren perdagangan luar negeri dan PMA kembali meningkat mulai triwulan ketiga 2020 didorong oleh kebijakan pemulihan ekonomi yang dilakukan berbagai negara di dunia, baik dalam bentuk insentif maupun subsidi.

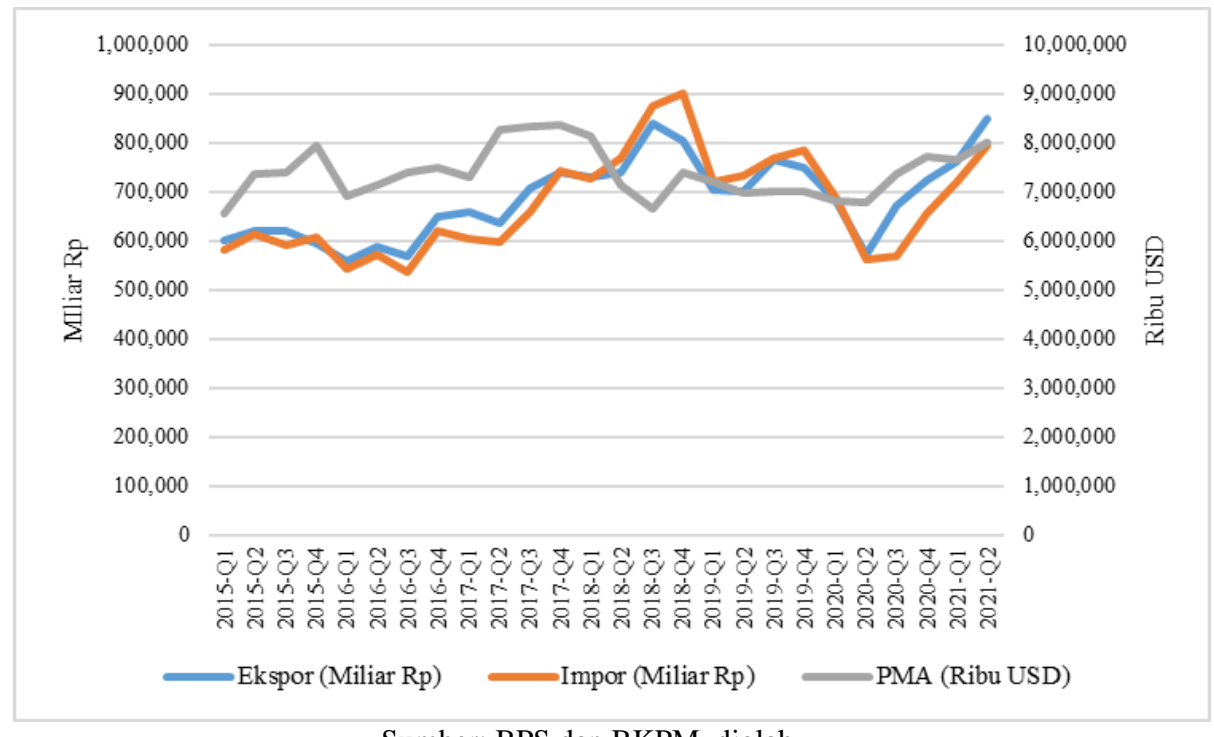

Sumber: BPS dan BKPM, diolah

GAMBAR 1. Nilai Ekspor, Impor dan PMA Indonesia Triwulan 1 2015-Triwulan 22021 
Berdasarkan nilai transaksi perdagangan luar negeri Indonesia dengan negara lain, nilai perdagangan luar negeri terbesar ditransaksikan antara Indonesia dan Tiongkok. Hal ini menjadikan Tiongkok sebagai mitra dagang paling utama Indonesia. Selain Tiongkok, negara dengan nilai transaksi perdagangan cukup besar dalam lima tahun terakhir adalah Jepang, Singapura dan Amerika Serikat.

TABEL 1. Nilai Transaksi Perdagangan Luar Negeri Indonesia Dengan Mitra Dagang Utama, 2015-2020 (Juta USD)

\begin{tabular}{lrrrrrr}
\hline Negara & $\mathbf{2 0 1 5}$ & $\mathbf{2 0 1 6}$ & $\mathbf{2 0 1 7}$ & $\mathbf{2 0 1 8}$ & $\mathbf{2 0 1 9}$ & \multicolumn{2}{c}{$\mathbf{2 0 2 0}$} \\
\hline Tiongkok & $44.456,2$ & $47.591,3$ & $58.849,9$ & $72.670,0$ & $72.892,5$ & $71.416,5$ \\
Jepang & $31.277,8$ & $29.083,4$ & $33.038,8$ & $37.442,4$ & $31.665,1$ & $24.336,8$ \\
Singapura & $30.654,8$ & $26.409,3$ & $29.613,4$ & $34.354,5$ & $30.506,6$ & $23.003,1$ \\
Amerika Serikat & $23.832,4$ & $23.439,9$ & $25.916,2$ & $28.616,0$ & $27.106,3$ & $27.202,7$ \\
Lainnya & $162.839,9$ & $154.315,1$ & $178.395,5$ & $195.641,1$ & $176.602,2$ & $158.801,5$ \\
\hline Total & $293.061,1$ & $280.839,0$ & $325.813,8$ & $368.724,0$ & $338.772,7$ & $304.760,6$ \\
\hline
\end{tabular}

Sumber: BPS, diolah

Dalam periode tahun 2015 hingga 2020, Singapura secara konsisten menjadi negara penanam modal asing terbesar di Indonesia. Beberapa negara lain yang konsisten menanamkan modal yang besar di Indonesia adalah Tiongkok, Jepang, dan Hongkong.

TABEL 2. Nilai Penanaman Modal Asing (PMA) Menurut Negara Asal, 2015-2020 (Juta USD)

\begin{tabular}{lrrrrrr}
\hline Negara & \multicolumn{1}{c}{$\mathbf{2 0 1 5}$} & $\mathbf{2 0 1 6}$ & $\mathbf{2 0 1 7}$ & $\mathbf{2 0 1 8}$ & $\mathbf{2 0 1 9}$ & $\mathbf{2 0 2 0}$ \\
\hline Singapura & $5.901,18$ & $9.178,69$ & $8.441,56$ & $9.193,18$ & $6.509,63$ & $9.779,11$ \\
Tiongkok & 628,34 & $2.665,30$ & $3.361,23$ & $2.376,54$ & $4.744,51$ & $4.842,41$ \\
Jepang & $2.876,99$ & $5.400,91$ & $4.996,16$ & $4.952,77$ & $4.310,91$ & $2.588,02$ \\
Hongkong & 937,20 & $2.248,33$ & $2.116,52$ & $2.011,42$ & $2.890,99$ & $3.535,90$ \\
Belanda & $1.307,78$ & $1.475,19$ & $1.489,42$ & 943,12 & $2.596,78$ & $1.422,38$ \\
Malaysia & $3.076,97$ & $1.115,56$ & $1.213,63$ & $1.774,90$ & $1.357,48$ & $1.045,27$ \\
Korea Selatan & $1.213,47$ & $1.065,80$ & $2.024,62$ & $1.604,72$ & $1.070,21$ & $1.841,95$ \\
Amerika Serikat & 893,16 & $1.161,94$ & $1.992,84$ & $1.217,62$ & 989,31 & 749,73 \\
Lainnya & $12.440,85$ & $4.652,35$ & $6.603,76$ & $5.233,63$ & $3.738,94$ & $2.861,52$ \\
\hline Total & $29.275,94$ & $28.964,07$ & $32.239,75$ & $29.307,91$ & $28.208,76$ & $28.666,27$ \\
\hline
\end{tabular}

Sumber: BKPM, diolah

Kondisi perekonomian negara mitra dagang utama dan negara investor terbesar di Indonesia turut memberikan dampak (langsung dan tidak langung) bagi kondisi perekonomian Indonesia. Berdasarkan GAMBAR 2 terlihat bahwa pada periode triwulan 1 tahun 2015 hingga triwulan IV 2019, pertumbuhan ekonomi Indonesia relatif stagnan. Salah satu penyebab stagnannya pertumbuhan ekonomi Indonesia pada periode ini adalah adanya kecenderungan perlambatan pertumbuhan ekonomi negara mitra dagang Indonesia, seperti Tiongkok, Jepang, Singapura dan Amerika Serikat. Mulai periode triwulan 1 tahun 2020 hingga triwulan 2 tahun 2021, pandemi COVID-19 menyebabkan hambatan besar dalam transaksi antar negara di dunia. Selain itu, pendemi juga menggoyahkan perekonomian internal setiap negara. Hal ini mengakibatkan resesi pertumbuhan ekonomi hampir di seluruh negara di dunia, tak terkecuali Indonesia dan seluruh mitra utamanya. 


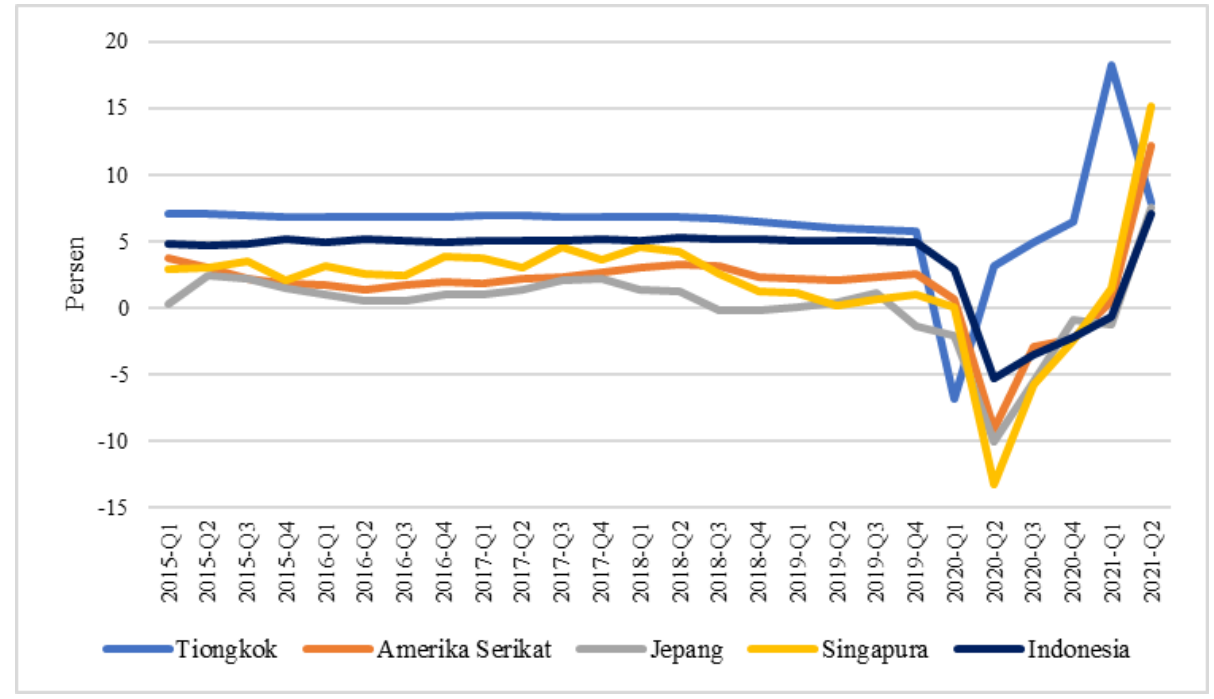

Sumber: Trading Economics

GAMBAR 2. Pertumbuhan Ekonomi Indonesia dan Negara Mitra Utama (y-on-y) Triwulan 1 2015-Triwulan 22021 (Persen)

Untuk mengetahui pengaruh ekspor, impor, dan PMA terhadap PDB Indonesia digunakan pemodelan Error Correction Mechanism (ECM). Pemodelan regresi data time series diawali dengan pengujian stasioneritas data, yang bertujuan untuk menghindari terbentuknya regresi palsu (spurious regression).

TABEL 3. Hasil Pengujian Stasioneritas Variabel Penelitian

\begin{tabular}{ccccc}
\hline \multirow{2}{*}{ Variabel } & \multicolumn{2}{c}{ Level } & \multicolumn{2}{c}{ First Difference } \\
\cline { 2 - 5 } & $\boldsymbol{p}$-value & Kesimpulan & $\boldsymbol{p}$-value & Kesimpulan \\
\hline $\ln$ PDB & 0,5154 & Tidak Stasioner & 0,0000 & Stasioner \\
lnEKS & 0,4005 & Tidak Stasioner & 0,0005 & Stasioner \\
lnIMP & 0,2015 & Tidak Stasioner & 0,0031 & Stasioner \\
lnPMA & 0,0697 & Tidak Stasioner & 0,0002 & Stasioner \\
\hline
\end{tabular}

Berdasarkan hasil Augmented Dickey-Fuller (ADF) test yang disajikan pada TABEL 3 diperoleh kesimpulan bahwa pada tingkat level seluruh variabel tidak stasioner karena nilai $p$-value untuk setiap variabel lebih besar dari tingkat signifikansi $(\alpha: 0,05)$, sehingga $\mathrm{H}_{0}$ gagal ditolak atau ada akar unit. Pada tingkat first difference, ADF test menghasilkan nilai $p$-value yang lebih kecil dari tingkat signifikansi $(\alpha: 0,05)$ untuk setiap variabel, sehingga $\mathrm{H}_{0}$ gagal ditolak atau tidak terdapat unit root dan dapat disimpulkan bahwa seluruh variabel stasioner pada first difference. Kondisi ini memunculkan dugaan akan adanya hubungan antara variabel bebas dan variabel terikat dalam jangka panjang (kointegrasi). Untuk itu, dilakukan regresi antara variabel terikat dan variabel bebas untuk membentuk persamaan jangka panjang dan dilakukan pengujian kointegrasi.

TABEL 4. Hasil Estimasi Persamaan Jangka Panjang

\begin{tabular}{crrrr}
\hline Variabel & Koefisien & Standart Error & t-Statistics & p-value \\
\hline C & 6,616161 & 2,378153 & 2,782058 & 0,0109 \\
lnEKS & 1,261381 & 0,192967 & 6,536756 & 0,0000 \\
InIMP & $-0,509434$ & 0,155051 & $-3,285590$ & 0,0034 \\
lnPMA & $-0,116657$ & 0,129535 & $-0,900588$ & 0,3776 \\
F-statistic & 17,408620 & & & \\
Prob(F-statistic) & 0,000005 & & & \\
Adjusted R-squared & 0,663190 & & & \\
\hline
\end{tabular}

Berdasarkan hasil regresi persamaan jangka panjang yang tersaji pada TABEL 4, dapat dibentuk persamaan jangka panjang yakni: 


$$
\ln P D B_{t}=6,616161+1,261381 \ln E K S_{t}^{*}-0,509434 \ln I M P_{t}^{*}-0,116657 \ln P M A_{t}
$$

Keterangan: ${ }^{*}$ Signifikan pada $\alpha: 0,05$

Nilai Prob(F-Statistic) dari persamaan jangka panjang adalah 0,000005 atau lebih kecil dari tingkat signifikansi ( $\alpha: 0,05)$. Sehingga hipotesis nol ditolak pada taraf signifikansi lima persen dan dapat dinyatakan setidaknya ada satu variabel bebas yang berpengaruh signifikan terhadap PDB. Secara parsial, nilai $p$-value variabel ekspor dan impor lebih kecil dari 0,05 yang berarti hipotesis nol ditolak, sedangkan nilai $p$-value dari PMA lebih besar dari 0,05 artinya hipotesis nol gagal ditolak. Dengan demikian dapat disimpulkan bahwa pada tingkat signifikansi lima persen, ekspor dan impor berdampak signifikan terhadap PDB pada jangka panjang, namun PMA tidak berdampak signifikan.

Selanjutnya untuk membuktikan adanya kointegrasi antar variabel penelitian, dilakukan pengujian stasioneritas residual dari persamaan jangka panjang dengan Augmented Dickey-Fuller (ADF) test.

TABEL 5. Hasil Pengujian Kointegrasi

\begin{tabular}{cccc}
\hline Variabel & t-Statistic & p-value & Kesimpulan \\
\hline Residual Persamaan Jangka Panjang $\left(\hat{\varepsilon}_{t}\right)$ & -4.111521 & 0.0041 & Stasioner \\
\hline Test critical values: (*MacKinnon (1996) & one-sided p-values) & \\
\hline 1\% level & -3.724070 & \\
5\% level & -2.986225 & \\
10\% level & -2.632604 & \\
\hline
\end{tabular}

Hasil ADF test pada Tabel 5 menunjukkan bahwa residual dari persamaan jangka panjang telah stasioner di tingkat level, sehingga dapat dibuktikan bahwa terdapat kointegrasi antara variabel satu dan lainnya. Hal ini berarti terdapat hubungan keseimbangan antar variabel terikat dan variabel bebas dalam jangka panjang. Berdasarkan Granger representation theorem, maka hubungan antar variabel ini dapat dijelaskan melalui ECM, dengan membentuk persamaan jangka pendek. Persamaan jangka pendek dibentuk dengan meregresikan first difference variabel terikat dengan first difference variabel bebas dan lag pertama residual persamaan jangka panjang atau Error Corection Term (ECT).

TABEL 6. Hasil Estimasi Persamaan Jangka Pendek (ECM Model)

\begin{tabular}{ccccc}
\hline Variabel & Koefisien & Standart Error & t-Statistics & p-value \\
\hline C & 0.007446 & 0.004474 & 1.664328 & 0.1116 \\
dlnEKS & 0.472371 & 0.122733 & 3.848758 & 0.0010 \\
dlnIMP & -0.187808 & 0.085340 & -2.200701 & 0.0397 \\
dlnPMA & -0.018428 & 0.076170 & -0.241932 & 0.8113 \\
ECT $_{t-1}$ & -0.328466 & 0.129787 & -2.530810 & 0.0199 \\
F-statistic & 4.272641 & & & \\
Prob(F-statistic) & 0.011654 & & & \\
Adjusted R-squared & 0.352935 & & & \\
\hline
\end{tabular}

Dari hasil regresi persamaan jangka pendek (ECM Model) yang disajikan pada TABEL 6, dapat dibentuk sebuah persamaan jangka pendek yaitu:

$$
d \ln P D B_{t}=0,007446+0,472371 d \ln E K S_{t}^{*}-0,187808 d \ln I M P_{t}^{*}-0,018428 d \ln P M A_{t}-0,328466 E C T_{t-1}^{*}
$$

Keterangan: ${ }^{*}$ Signifikan pada $\alpha: 0.05$

Nilai Prob(F-Statistic) persamaan jangka pendek sebesar 0.011654 atau lebih kecil dari tingkat signifikansi ( $\alpha$ : 0.05). Sehingga hipotesis nol ditolak pada taraf signifikansi lima persen dan dapat dinyatakan setidaknya ada satu variabel bebas dengan pengaruh signifikan terhadap PDB. Secara parsial, nilai $p$-value variabel ekspor dan impor lebih kecil dari 0.05 yang artinya hipotesis nol ditolak. Sehingga dapat disimpulkan bahwa dengan tingkat signifikansi lima persen, variabel ekspor dan impor berpengaruh signifikan terhadap PDB dalam jangka pendek, sedangkan variabel PMA tidak berpengaruh signifikan. 
Adjusted R-Squared persamaan jangka pendek bernilai sebesar 0.352935 menunjukkan bahwa secara bersama-sama, ketiga variabel bebas yakni ekspor, impor, dan PMA mampu menjelaskan 35.29 persen keragaman PDB Indonesia. Sementara sisanya sebesar 64.71 persen dari keragaman dijelaskan peubah lain di luar enelitian.

Nilai koefisien ECT pada persamaan jangka pendek telah telah memenuhi syarat ECM model. Karena nilai koefisien ECT bernilai negatif dalam rentang -1 hingga 0 dan signifikan dalam model dengan tingkat signifikansi 5 persen.

Pembentukan model ECM dilakukan dengan estimasi Ordinary Least Square (OLS), sehingga diberlakukan asumsi klasik Gauss-Markov yakni asumsi normalitas, non autokorelasi, homoskedastititas, dan non multikolinieritas. Berdasarkan TABEL 7, seluruh asumsi klasik telah terpenuhi, sehingga dapat dinyatakan bahwa penduga yang dihasilkan memenuhi kriteria BLUE (Best Linear Unbiassed Estimator).

TABEL 7. Hasil Uji Asumsi Klasik

\begin{tabular}{llccc}
\hline \multicolumn{1}{c}{ Asumsi Klasik } & \multicolumn{1}{c}{ Uji Statistik } & $\boldsymbol{p}$-value & Keputusan & Kesimpulan \\
\hline Normalitas & Jarque-BeraTest & 0.413956 & Gagal Tolak $\mathrm{H}_{0}$ & Terpenuhi \\
Non Autokorelasi & Breusch-Godfrey Test & 0.805400 & Gagal Tolak $\mathrm{H}_{0}$ & Terpenuhi \\
Homoskedastisitas & Breusch-Pagan-Godfrey Test & 0.750100 & Gagal Tolak $\mathrm{H}_{0}$ & Terpenuhi \\
Non Multikolinieritas & Variance Inflation Factors (VIF) & - & Nilai VIF<10 & Terpenuhi \\
dlnEKS & 2.826659 & & & \\
dlnIMP & 2.528439 & & & \\
dlnPMA & 1.236361 & & & \\
ECT $_{\mathrm{t}-1}$ & 1.450773 & & & \\
\hline
\end{tabular}

Nilai koefisien ECT menginformasikan tentang tingkat kecepatan koreksi ketidakseimbangan periode waktu sebelumnya pada kondisi saat ini. Dari pemodelan ECM yang dilakukan, diperoleh koefisien ECT sebesar -0.328466, yang berarti ketidakseimbangan pada periode waktu sebelumnya akan dikoreksi sebesar 32.85 persen pada periode sesudahnya sebagai akibat dari pengaruh jangka pendek dari variabel ekspor, impor, dan PMA. Kemudian ketidakseimbangan yang tersisa sebesar 67.15 persen akan dikoreksi pada periode berikutnya.

Pada jangka panjang maupun pendek, dengan tingkat signifikansi lima persen variabel ekspor berpengaruh signifikan dan positif terhadap PDB Indonesia, sedangkan impor berpengaruh signifikan dan negatif terhadap PDB Indonesia. Dari model ECM, diperoleh nilai koefisien pertumbuhan ekspor adalah 0.472371 yang berarti bahwa setiap peningkatan ekspor luar negeri sebesar satu persen, akan meningkatkan PDB sebesar 0.472371 persen dengan asumsi ceteris paribus. Nilai koefisien pertumbuhan impor dalam model ECM yang terbentuk adalah -0.187808 artinya setiap kenaikan impor luar negeri sebesar satu persen, akan menurunkan PDB sebesar 0.187808 persen dengan asumsi ceteris paribus.

Temuan ini sesuai dengan penelitian yang dilakukan oleh Ginting (2017), dimana dalam jangka waktu panjang dan juga pendek, ekspor berdampak signifikan dan positif pada pertumbuhan ekonomi Indonesia, sebaliknya impor berdampak signifikan namun negatif untuk pertumbuhan ekonomi. Hasil penelitian ini juga mendukung temuan Sumiyarti (2015) yang menyatakan bahwa dugaan ELG atau Export Led Growth juga berlaku pada kondisi ekonomi Indonesia. Ekspor menjadi mesin pendorong pertumbuhan ekonomi Indonesia, terutama ekspor barang manufaktur.

Dengan demikian, pertumbuhan ekonomi Indonesia dapat diakselerasi dengan meningkatkan kinerja ekspor. Beberapa upaya untuk meningkatkan kinerja ekspor adalah efektifitas sistem administrasi, riset dan pengembangan komoditas ekspor, peningkatan infrastruktur perdagangan internasional, menjaga stabilitas kurs serta perluasan pasar non tradisional (Ginting, 2017). Selain itu, untuk mendorong peningkatan kinerja ekspor, diperlukan strategi yang konsisten dari tahun ke tahun. Kementerian Perdagangan (2021) menetapkan lima strategi peningkatan ekspor yakni menjaga pasar dan produk utama ekspor, meningkatkan perhatian terhadap usaha kecil dan menengah (UKM) yang berorientasi ekspor, melakukan penetrasi pasar nontradisional, pemanfaatan perjanjian dagang, dan melakukan reformasi regulasi terutama turunan Undang-Undang Cipta Kerja. 
Dampak negatif yang diberikan oleh variabel impor terhadap pertumbuhan ekonomi dapat diantisipasi dengan menerapkan kebijakan impor yang menguntungkan bagi industri dalam negeri. Beberapa kebijakan impor yang dapat diterapkan adalah kebijakan tarif, kuota impor, subsidi, dan larangan impor.

Penelitian ini menghasilkan temuan lain yakni dengan tingkat signifikansi lima persen, pada jangka waktu panjang maupun pendek variabel PMA tidak memberikan pengaruh signifikan terhadap pertumbuhan ekonomi Indonesia. Hasil ini mendukung penemuan Hawari \& Kartiasih (2016) dalam penelitiannya mengenai dampak aktivitas luar negeri terhadap pertumbuhan ekonomi Indonesia selama periode 1998 hingga 2014 yang menyatakan bahwa dalam jangka pendek PMA tidak memberikan pengaruh signifikan bagi pertumbuhan ekonomi Indonesia. Meskipun pada jangka panjang PMA memberikan dampak yang signifikan, namun dampak yang diberikan berarah negatif.

Supriyadi \& Satria (2017) dalam penelitiannya mengenai hubungan kausalitas antara PMA dan pertumbuhan ekonomi dengan Toda-Yamamoto Granger Causality Model di ASEAN-5 (Indonesia, Malaysia, Thailand, Singapura dan Filipina) menemukan bahwa PMA tidak berdampak signifikan terhadap pertumbuhan ekonomi, namun sebaliknya pertumbuhan ekonomi berdampak siginifikan terhadap PMA di Indonesia dan Malaysia. Melalui pendekatan model uji kausalitas Granger, Amalia (2013) dan Fazaalloh (2019) juga menyimpulkan bahwa PMA tidak berpengaruh signifikan tehadap pertumbuhan ekonomi Indonesia, justru pertumbuhan ekonomi berpengaruh signifikan terhadap aliran masuk PMA di Indonesia. Menurut Fazaalloh (2019), PMA tidak memberikan dampak signifikan terhadap pertumbuhan ekonomi di Indonesia dikarenakan sumber daya manusia Indonesia belum menyerap transfer teknologi dan pengetahuan secara maksimal. Untuk itu diperlukan peningkatan kapasitas sumber daya manusia untuk mewujudkan efisiensi investasi dalam bentuk transfer modal dan teknologi.

\section{KESIMPULAN DAN SARAN}

Perdagangan luar negeri dan PMA secara simultan berpengaruh signifikan terhadap PDB Indonesia pada tingkat signifikansi lima persen. Secara parsial, variabel ekspor serta impor berpengaruh signifikan terhadap PDB, baik dalam jangka pendek maupun jangka panjang. Variabel ekspor berpengaruh positif terhadap PDB, sedangkan variabel impor berpengaruh negatif. Pada sisi lain, PMA tidak berpengaruh signifikan terhadap PDB, baik dalam jangka waktu pendek maupun panjang.

Dalam rangka mengefisienkan efek positif dari perdagangan luar negeri Indonesia, maka strategi peningkatan ekspor perlu diimplementasikan dengan baik. Selain itu, perlu dilakukan pengkajian pemilihan dan penerapan kebijakan impor yang menguntungkan bagi industri dalam negeri. Kemudian untuk meningkatkan dampak penanaman modal asing terhadap perekonomian Indonesia, peningkatan efektivitas transfer modal dan teknologi dari luar negeri merupakan suatu prasyarat yang harus dipenuhi. Untuk itu diperlukan peningkatan kapasitas sumber daya manusia agar penyerapan teknologi dapat lebih maksimal.

\section{UCAPAN TERIMA KASIH}

Apresiasi dan ucapan terima kasih disampaikan penulis kepada Kementerian Investasi/BKPM dan BPS atas penyediaan data berkualitas yang digunakan dalam penelitian ini. Selain itu, penulis juga menyampaikan terima kasih kepada seluruh pihak atas sumbangan gagasan dan saran konstruktif selama penelitian.

\section{REFERENSI}

Alotaibi, M. E., Almohaimeed, M. A. \& Alharbi, W. M., 2020, 'The Impact of International Trade on Economic Growth', Journal of Modern Accounting and Auditing, vol. 16, no. 11, hh. 484-501.

Amalia, F., 2013, 'Hubungan Kausalitas Investasi Dengan Pertumbuhan Ekonomi Indonesia', Signifikan: Jurnal Ilmu Ekonomi, vol. 2, no. 1, hh. 1-16. 
Amalia, K., Kiftiah, M. \& Sulistianingsih, E., 2016, 'Penerapan Teori Solow-Swan pada Pertumbuhan Ekonomi', Bimaster: Buletin Ilmiah Matematika, Statistika dan Terapannya, vol. 5, no. 1, hh. 3944.

Astuti, I. P. \& Ayuningtyas, F. J., 2018, 'Pengaruh Ekspor Dan Impor Terhadap Pertumbuhan Ekonomi Di Indonesia', Jurnal Ekonomi \& Studi Pembangunan, vol. 19, no. 1, hh. 1-10.

Astuti, P. Y. \& Saputro, D. R. S., 2018, 'Kointegrasi dan Estimasi Error Correction Model (ECM)Engle-Granger', Program Studi Pendidikan Matematika FKIP Universitas Ahmad Dahlan (UAD), Yogyakarta, hh. 131-135.

BPS, 2021, Produk Domestik Bruto Indonesia Menurut Pengeluaran 2016-2020, Badan Pusat Statistik, Jakarta.

Enders, W., 2015, Applied Time Series Econometrics, $4^{\text {th }}$ edn, John Wiley \& Sons, Inc., New Jersey.

Fazaalloh, A. M., 2019, 'Foreign Direct Investment and Economic Growth In Indonesia: A Causality Analysis’, Jurnal Ekonomi Kuantitatif Terapan, vol. 12, no. 1, hh. 47-54.

Ginting, A. M., 2017, ‘Analisis Pengaruh Ekspor Terhadap Pertumbuhan Ekonomi Indonesia', Buletin Ilmiah Litbang Perdagangan, vol. 11, no. 1, hh. 1-20.

Gujarati, D. N. \& Porter, D. C., 2009, Basic Econometrics, $5^{\text {th }}$ edn, McGraw-Hill/Irwin, New York.

Hawari, R. \& Kartiasih, F., 2016, 'Kajian Aktivitas Ekonomi Luar Negeri Indonesia Terhadap Pertumbuhan Ekonomi Indonesia Periode 1998-2014', Media Statistika, vol. 9, no. 2, hh. 119-132.

Iladini, K. \& Agustina, N., 2020, 'Analisis Time Series Pendekatan Error Correction Mechanism: Pengaruh Penerapan ACFTA Terhadap Ekspor Kopi Indonesia ke China Periode 2006-2018', Jurnal Statistika dan Aplikasinya (JSA), vol. 4, no. 2, hh. 82-94.

Kementerian Perdagangan, 2021, Siaran Pers: Pra-Raker: Kemendag Tetapkan Strategi Peningkatan Ekspor, Kementerian Perdagangan, Jakarta.

Lawal, E. O. \& Ezeuchenne, K., 2017, 'International Trade and Economic Growth in Nigeria', IOSR Journal of Humanities and Social Science, vol. 22, no. 6, hh. 35-43.

Mankiw, N. G., 2018, Principles of Economics, $8^{\text {th }}$ edn, Cengage Learning, Boston.

Nguyen, H. H., 2020, 'Impact of Foreign Direct Investment and International Trade on Economic Growth: Empirical Study in Vietnam', Journal of Asian Finance, Economics and Business, vol. 7, no. 3, hh. 323-331.

Purnama, P. D. \& Yao, M. H., 2019, 'The Relationship between International Trade and Economic Growth: An Empirical Finding from ASEAN Countries', International Journal of Applied Business Research, vol. 1, no. 2, hh. 112-123.

Purnomo, R. N., 2020, 'Analisis Pengaruh Keterbukaan Ekonomi Terhadap Pertumbuhan Ekonomi (Studi Kasus: ASEAN Tahun 2007-2017)', Jurnal Dinamika Ekonomi Pembangunan, vol. 2, no.2, hh. 20-35.

Raghuramapatruni, R. \& Chaitanya, R. V. S., 2020, 'An Appraisal of the Impact of International Trade on Economic Growth of India- through the ARDL Approach', International Journal of Economics and Business Administration, vol. VIII, no. 2, hh. 376-387.

Republik Indonesia, 2007, Undang Undang Republik Indonesia Nomor 25 Tahun 2007 Tentang Penanaman Modal, Republik Indonesia, Jakarta.

Safitri, Z. \& Yuliana, L., 2020, 'Penerapan Model Error Correction Mechanism: Determinan Produksi Kopi di Indonesia Periode 2002-2018’, Jakarta, Politeknik Statistika STIS, hh. 946-956. 
Sugiarto, S. \& Merissa, W., 2016, 'Error Correction Mechanism (ECM) Analysis for Identifying Factors that Influence Tax Income in Indonesia', Jurnal Aplikasi Statistika \& Komputasi Statistik, vol. 8, no. 1, hh. 17-26.

Sumiyarti, S., 2015, ‘Apakah Hipotesis “Export Led Growth” Berlaku di Indonesia?’, Jurnal Ekonomi dan Studi Pembangunan, vol. 16, no. 2, hh. 188-199.

Supriyadi, D. \& Satria, D., 2017, 'Model of Causality Between FDI and Gross Domestic Product on ASEAN-5 Countries From 1980-2014', Journal of Indonesian Applied Economics, vol. 7, no. 1, hh. 1-17.

Susanti, E. \& Sholeh, M., 2020, 'Indonesia Economic Growth Determinant: The Impact Of Macro Economic Variables And International Trade', International Journal of Economics and Financial Issues, vol. 10, no. 5, hh. 70-76.

World Bank, 2021, The World Bank - Indonesia Overview, (Online) Tersedia pada: https://www.worldbank.org/en/country/indonesia/overview\#1 (Diakses 19 December 2021). 